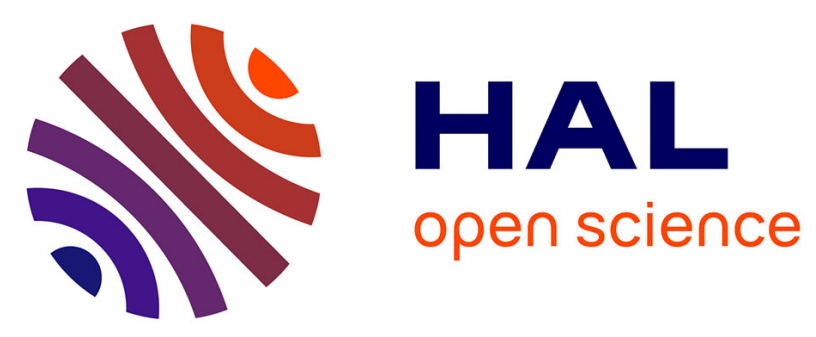

\title{
Coupled Rock-Eval pyrolysis and spectrophotometry for lacustrine sedimentary dynamics: Application for West Central African rainforests (Kamalété and Nguène lakes, Gabon)
}

David Sebag, Maxime Debret, M. Mvoubou, R.M. Obame, A. Ngomanda, R. Oslisly, Ilham Bentaleb, Jean-Robert Disnar, P Giresse

\section{To cite this version:}

David Sebag, Maxime Debret, M. Mvoubou, R.M. Obame, A. Ngomanda, et al.. Coupled RockEval pyrolysis and spectrophotometry for lacustrine sedimentary dynamics: Application for West Central African rainforests (Kamalété and Nguène lakes, Gabon). The Holocene, 2013, pp.1- 11. 10.1177/0959683613483622hol.sagepub.com . hal-00861195

\section{HAL Id: hal-00861195 https://hal.science/hal-00861195}

Submitted on 31 Jan 2014

HAL is a multi-disciplinary open access archive for the deposit and dissemination of scientific research documents, whether they are published or not. The documents may come from teaching and research institutions in France or abroad, or from public or private research centers.
L'archive ouverte pluridisciplinaire HAL, est destinée au dépôt et à la diffusion de documents scientifiques de niveau recherche, publiés ou non, émanant des établissements d'enseignement et de recherche français ou étrangers, des laboratoires publics ou privés.

\section{(이) $\$$}

Distributed under a Creative Commons Attribution - NonCommercial - NoDerivatives $\mid 4.0$ 


\title{
Coupled Rock-Eval pyrolysis and spectrophotometry for lacustrine sedimentary dynamics: application for West Central African rainforests (Kamalété and Nguène, Gabon)
}

David SEBAG ${ }^{1,2}$, Maxime DEBRET ${ }^{1}$, MAKAYA MVOUBOU ${ }^{3}$, Rolf MABICKA OBAME ${ }^{1,3}$, Alfred NGOMANDA $^{4}$, Richard OSLISLY ${ }^{5}$, Ilham BENTALEB ${ }^{6}$, Jean-Robert DISNAR ${ }^{7}$, Pierre GIRESSE $^{8}$

${ }^{1}$ Université de Rouen, Laboratoire M2C, CNRS, Mont-Saint-Aignan, France.

${ }^{2}$ IRD, Laboratoire HydroSciences Montpellier, Université de Ngaoundéré, Cameroun.

${ }^{3}$ Université des Sciences et Techniques de Masuku, URESTE, Franceville, Gabon.

${ }^{4}$ Institut de Recherches en Ecologie Tropicale, CENAREST, Libreville, Gabon.

${ }^{5}$ IRD, Laboratoire PALOC, Agence Nationale des Parc Nationaux, Libreville, Gabon.

${ }^{6}$ Université de Montpellier II, Laboratoire ISEM, CNRS, Montpellier, France.

${ }^{7}$ CNRS, Institut des Sciences de la Terre d'Orléans, Université d'Orléans, Orléans, France.

${ }^{8}$ Université de Perpignan, Laboratoire CEFREM, Perpignan, France.

Corresponding author: david.sebag@univ-rouen.fr

\begin{abstract}
Published online before print April 24, 2013
Abstract

In recent years, Nguène Lake and Kamalété Lake (Gabon, West Central Africa) have been studied repeatedly, providing comprehensive reconstructions of environmental changes over the last millennia. Both lakes are in different geomorphological and environmental settings. They are therefore excellent sites to test new methodological approaches. Indeed, the sedimentary cores provide various facies, and the previous studies provide references for calibrating the results of new methods. In this methodological issue, the present study aims to evaluate the potential of spectrophotometric and Rock-Eval coupled analysis to describe the Holocene lake and marsh deposits from tropical moist forests. This assessment is carried out on samples taken from two well-documented reference cores. The spectrophotometric analysis provides reproducible colour measurements, which inform about the nature of the main colour-bearing constituents. Coupled with Rock-Eval pyrolysis, this technique can be used to describe lithological changes and identify the probable source of sedimentary organic matter. In the studied cases, this approach identified the facies dominated by detrital terrigenous inputs ("iron bearing" signature and high OI values) and those associated with a more abundant primary production ("chlorophyll" signature, low OI and high HI), providing a distinction between palustrine and lacustrine dynamics. However, although the facies are comparable, sedimentary dynamics and sediment sources may vary depending on geomorphological and climatic contexts.
\end{abstract}

Keywords: sedimentology, tropical lake, diffuse reflectance, organic matter, Africa

\section{Introduction}

Numerous studies in West Central Africa help to draw a clear picture of the evolution of tropical rainforests during the Quaternary and Holocene (e.g., Marchant \& Hooghiemstra, 2004; Bonnefille, 2011), especially from marine records (Dupont et al., 2000; Lézine et al., 2005; Weldeab et al., 2007; Kim et al., 2010). However, continental reference sites and continuous series from Central Africa (Maley \& Brenac, 1998; Marret et al., 2006) are too scattered to assess the palaeohydrological models recently developed for higher-resolution studies (e.g., Ward et al., 2007). Therefore, recent works have focused on several complementary approaches to study some lacustrine key sites of West Central
Africa, such as Ossa (Nguetsop et al., 2010; Kossoni \& Giresse, 2010), Nyabessan (Ngomanda et al., 2009; Sangen, 2010), and Kamalété and Nguène (Ngomanda et al., 2005; Giresse \& Makaya-Mvoubou, 2010). In these studies, the analytic methodologies are based on a combination of sedimentological (e.g., grain size, X-ray diffraction), palaeoecological (e.g., pollens, diatoms), and geochemical techniques (e.g., C/N, $\delta 13 \mathrm{C}, \delta 15 \mathrm{~N}$ ) to reconstruct palaeoenvironments and palaeoclimates. However, the routine application of this multidisciplinary approach is limited by the time-consuming procedures of pretreatments and non-continuous measurements. On the other hand, non-destructive methods exist such as X-ray fluorescence core scanner or Scopix techniques. 
Such approaches have been proved useful for assessing potential palaeoclimatic records by continuous measurements from sedimentary sequences. Yet, they often require large and expensive equipment.

Spectrophotometric analysis offers probably a good compromise: portable and easy to use, quick high-resolution data acquisition from chromatic properties of sediments. Mainly used for marine and lacustrine investigations (e.g., Mix et al., 1995; Debret et al., 2010, 2011), this method has recently been used to study changes in the composition of Quaternary sediments off the Gabon coasts in order to reconstruct millennial-scale precipitation changes (Itambi et al., 2010).

The present study aims to evaluate the potential of sediment colour to describe the Late Holocene lake and marsh deposits from West Central Africa moist forests. Combined with Rock-Eval analysis of sedimentary organic matter (OM), this assessment is carried out on samples taken from two welldocumented reference cores (KAM1 and NGUE1; e.g., Ngomanda et al., 2007; Giresse et al., 2009). Indeed, the studied sites (Kamalété and Nguène Lakes, Gabon) present sufficiently contrasting characteristics to provide reference terms for future studies using the same methodology. In this methodological issue, the results will be compared to conclusions from previous studies, which they may supplement about sources of sedimentary constituents.

\section{Geographical settings and studied cores}

\subsection{Kamalété Lake}

Kamalété Lake is a closed and small marshy basin (50 to $100 \mathrm{~m}$ wide, 500 to $700 \mathrm{~m}$ long, $\sim 2 \mathrm{~m}$ depth). The basin covers $\sim 0.1 \mathrm{~km} 2$ with a water depth that falls to $1 \mathrm{~m}$ during the dry season. It located southeast of Lopé National Park (Ogooué-Ivindo, Gabon; $0^{\circ} 43^{\prime} \mathrm{S}, 11^{\circ} 46^{\prime} \mathrm{E}$; $350 \mathrm{~m}$ asl; Figure 1) in a narrow structural depression in the Early Proterozoic formations (Francevillian) composed of mudstones, micaceous and clayey sandstones, feldspathic sandstones, cherts, dolomites and shales (Weber, 1968). The yellow ferrallitic soils have a clay texture to sandy clay and are composed of kaolinite, illite, quartz, goethite, gibbsite, and feldspars (Collinet and Forget, 1976; Chatelin, 1966). Coarse particles (i.e. pebbles) and traces of gullies show that the catchment suffered an intense erosion by runoff. Either side of the lake, steep slopes are marked by landslides of tens of cubic meter and by outcrops of ferruginous crusts. Some hydromorphic soils (gley or pseudo-gley) are visible on the marshy banks of the lake. In the surrounding area, vegetation is characterized by a colonizing forest/savanna mosaic. The lake is surrounded by a heterogeneous vegetation (savannah and colonizing forest) that combines grassy species (Pobeguinea arrecta) and pioneer species (Uapacca guineensis, Aucoumea klaineana). Pioneer species reflect the long-term transition from a savannah toward a forest environment. On the banks, a ring of ferns (Gleichenia) and sedges grow randomly in shallow waters. Annual precipitation oscillates are around $1,500 \mathrm{~mm}$, a low value for Gabon due to the rain shadow effect of the Cristal Mounts and Massif of Chaillu on the western side. But, present day meteorological values show great inter-annual variability related to variable timing and duration of the dry summer season: the minimum rainfall are recorded from mid-June to mid-September and from mid-December to mid-January, while the highest are in the other months of the year. Average annual temperatures are between 20.6 and $30.8^{\circ} \mathrm{C}$. They are highest in the rainy season (FebruaryApril) and minimum in the dry season (JuneAugust) because of the cloud cover reduces insolation.

The 375-cm-long core KAM1 (Figure 2) was taken in the central part of Kamalété Lake (e.g., Ngomanda et al., 2007; Giresse et al., 2009). From the base to $149 \mathrm{~cm}$, sedimentation began with beige mud. Abundant siderite aggregates and organic and silty laminae several millimetres thick were noted in this lithological unit. The upper 149-cm-thick interval is a grey to grey-green mud with lower abundance of sand and a darker colour. Lamination frequency changes in different sections of the core: numerous laminations were observed in the beige mud, while only few laminations were observed in the grey-green mud.

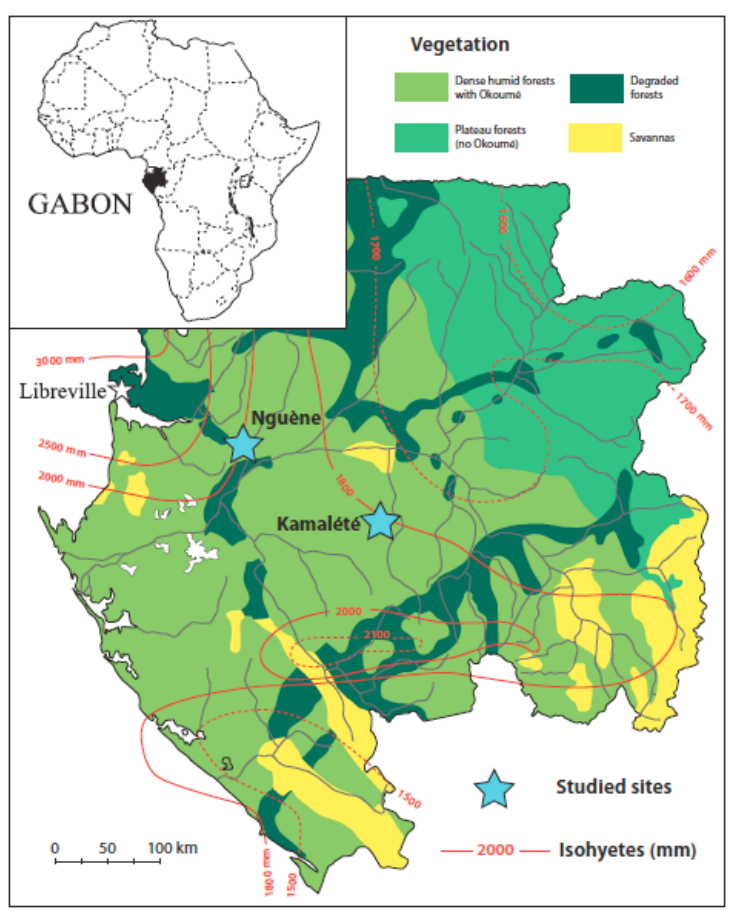


Figure 1: Map of Gabon showing dominant vegetation, isohyets, and site locations.

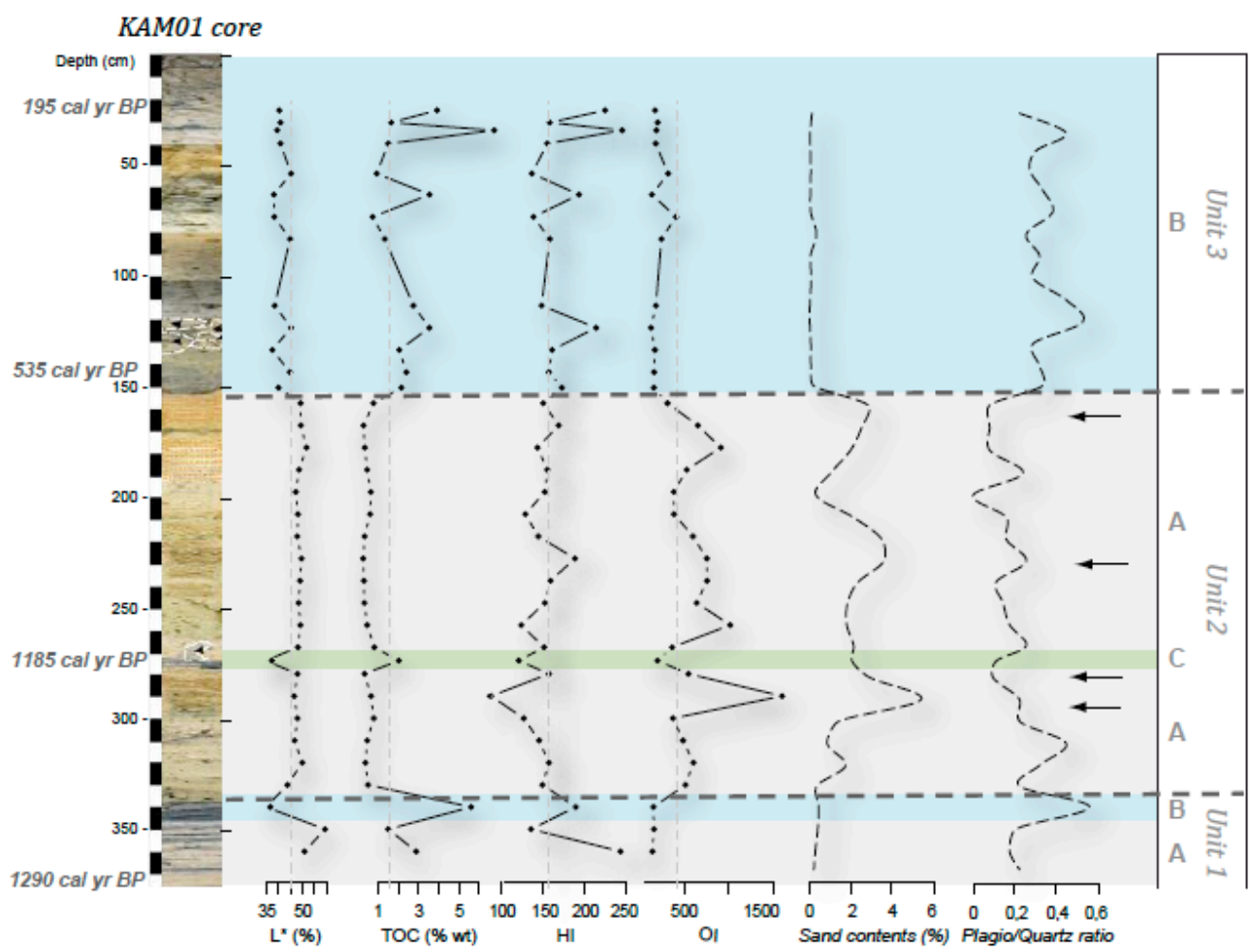

Figure 2: Down core variations of reflectance and classical PyRE parameters showing main lithological units and some compositional changes in the KAM1 core. Coloured bands correspond to spectral signatures (A, B, and C) defined from FDS (see text and Fig. 5).

\subsection{Nguène Lake}

Nguène Lake is located on the southern slopes of the Cristal Mounts (Moyen-Ogooué, Gabon; $0^{\circ} 12^{\prime} \mathrm{S}, 10^{\circ} 28^{\prime} \mathrm{E} ; 20 \mathrm{~m}$ asl; Figure 1$)$. It was primarily a fluvial depression, today partly isolated from the Abanga River. The shallow lake ( $\sim 3$ to 5 $\mathrm{m}$ depth) covers ca. $3 \mathrm{~km} 2$ during the dry season (< $2 \mathrm{~m}$ depth). The swampy shore is largely flooded during the rainy season. In the southeastern part, a communication with the river plays seasonally as a water supply or drain.

The basin is located in the clayey PermianCarboniferous formations between the Lambaréné horst and the Precambrian basement. Most rocks that outcrop along the Abanga River are part of sandy-clayey Permo-Carboniferous series of N'khom and Agula (Bassot, 1988). Common soils are ferrallitic soils developed on sandstones, providing a sandy clayey texture and composed of kaolinite, illite (scarce), quartz, goethite and feldspars (Collinet and Martin, 1973). In the area, is covered by a dense evergreen rainforest characteristic of the regional climate. The catchment area $(\sim 6 \mathrm{~km} 2)$ is colonized by a swamp forest dominated by Anthostema aubryanum (Euphorbiaceae), Uapacca spp. (with highly developed aerial roots) and Alstonia congensis (Apocynaceae). Near the banks (especially in the northwest part), the abundance of Cyperus papyrus (Cyperaceae) show the recent evolution of this swampy area. Average rainfall is about $2150 \mathrm{~mm}$ (Collinet and Martin, 1973) with a maximum between March and May (long rainy season) and minimum between June and August (long dry season). Temperatures (around $26^{\circ} \mathrm{C}$ ) are highest during rainy season and lowest during dry season.

The 415-cm-long core NGUE1 (Figure 3) was taken from the southern part, $200 \mathrm{~m}$ from the western bank (e.g., Ngomanda et al., 2007; Giresse et al., 2009). From the base to $152 \mathrm{~cm}$, sediments began with light to dark grey hydromorphic deposits, including some sandy layers and bioturbation structures. This grey mud is similar to gley forming on the current banks. The upper 152 $\mathrm{cm}$ show a dark clayey mud with conspicuous dark and light grey alternations. Crystals of siderite and vivianite accompany the clayey and organic accumulations. However, these iron concretions are more abundant in the lowermost deposits. 


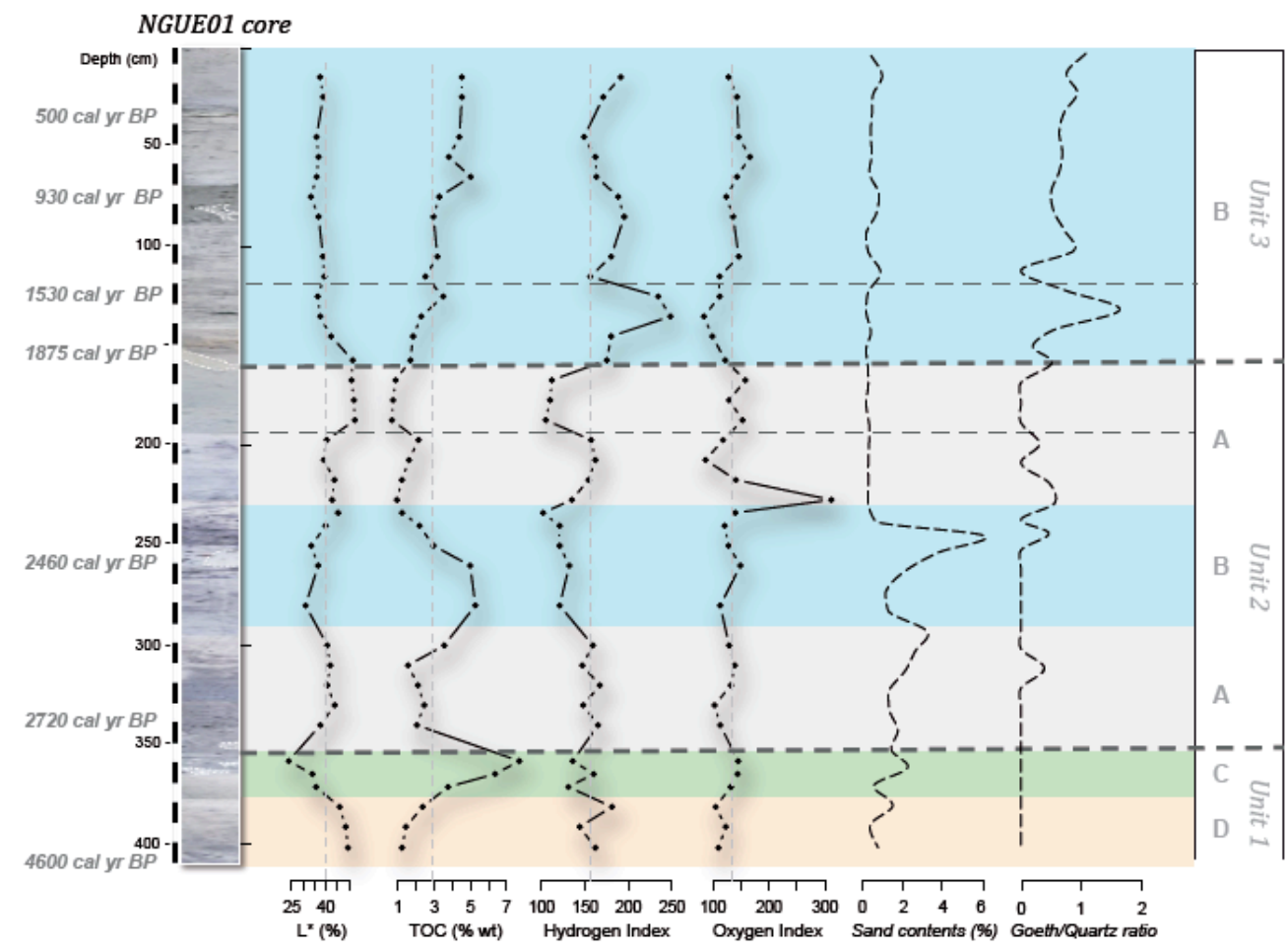

Figure 3: Down core variations of reflectance and classical PyRE parameters showing main lithological units and some compositional changes in the NGUE1 core. Coloured bands correspond to spectral signatures (A, B, C and D) defined from FDS (see text and Fig. 6).

\section{Methodology}

The present work aims to highlight the complementarity of two techniques often used separately: the spectrophotometry, which provides continuous measurements of the sediment colour, and the Rock-Eval pyrolysis, which provides qualitative and quantitative data on the sedimentary organic matter. Both techniques are detailed below. In the discussion section, we show the interest of these two methods by comparing the results obtained here with previously published results including mineralogical and palynological data. For details of these conventional methods, lithological description and chronological discussion, we refer to these previous articles (Ngomanda et al., 2005; Ngomanda et al., 2007; Giresse et al., 2009; Giresse \& Makaya-Mvoubou, 2010).

\subsection{Spectrophometry (visible reflectance)}

Analyses were carried out using a Minolta CM 2600d, commonly used for quantitative measurements of soil and sediment colour (Croft \& Pye, 2004). This instrument provides reflectance measurements in the visible wavelengths (400-700 $\mathrm{nm}$ ). We used specular component excluded (SCE) reflectance to eliminate any bias induced by specular reflection. The illuminant was D65, corresponding to the average daylight at a temperature of $6504 \mathrm{~K}$. Measurements were taken with a $8 \mathrm{~mm}$ aperture.
For binary mixtures of contrasted components (i.e., dark/light), CIELab standard parameters (L*, $\mathrm{a}^{*}$, and $\left.\mathrm{b}^{*}\right)$ can eventually be used for palaeoenvironmental or palaeoclimatic implications (Mix et al., 1992; Debret et al., 2006). For more complex mixtures, however, other parameters have to be used and various approaches have been proposed (e.g., first derivative methods, frequencies gathering, factor analyses) to characterize the sedimentary facies (Balsam \& Beeson, 2003 ; Ji et al., 2005) or quantify constituents such as carbonates, goethite, hematite, or chlorite (e.g., Damuth \& Balsam, 2003; Zhang et al., 2007; Ortiz et al., 2009 ; see Debret et al, 2011 for a review).

In this work, we used two complementary tools (i) $\mathrm{L}^{*}$ as a measure of lightness ranging from 0 (black) to 100 (white) to establish a lithological division, and (ii) and the first derivative spectra (FDS) to analyse the composition of sediments, and to describe the changes in sedimentary dynamics.

\subsection{Bulk geochemical analyses: Rock Eval pyrolysis}

The Rock-Eval pyrolysis technique was designed to screen automatically, without any preliminary treatment, large sets of rock and sediment samples (Espitalié et al., 1985). Initially designed for petroleum applications, this routine method is now used for a large variety of materials, e.g., soils and recent sediments (Sifeddine et al., 1995; Patience et al., 1996; Meyers \& Lallier-Vergès, 1999; Disnard 
et al., 2003; Marchand et al., 2003; Hetényi et al., 2005; Sanei et al., 2005; Sebag et al., 2006).

The sampling interval was approximately $10 \mathrm{~cm}$ for lithologic logging for the KAM1 and NGUE1 cores, but the intervals were shortened depending on facies thickness. Analysis was carried out with $100 \mathrm{mg}$ of powder sample using a "Turbo" RockEval 6 pyrolyzer manufactured by Vinci Technologies. Standard parameters, namely, total organic carbon (TOC), hydrogen index (HI), and oxygen index (OI), were calculated by integrating the amounts of hydrocarbon compounds ( $\mathrm{HC}), \mathrm{CO}$, and $\mathrm{CO} 2$ produced during thermal cracking of the OM, between well-defined temperature limits (Espitalié et al., 1985; Lafargue et al., 1998; Behar et al., 2001). TOC (in \% wt) is the sum of all the organic carbon moieties ( $\mathrm{HC}, \mathrm{CO}$, and $\mathrm{CO} 2)$. TpS2 (in ${ }^{\circ} \mathrm{C}$ ) is the corrected temperature of the oven, which corresponds to the optimum $\mathrm{HC}$ release. HI (in mg HC g-1 TOC) corresponds to the quantity of $\mathrm{HC}$ released relative to $\mathrm{TOC}$, and is correlated to the $\mathrm{H} / \mathrm{C}$ ratio. $\mathrm{OI}$ (in $\mathrm{mg} \mathrm{O} 2 \mathrm{~g}-1 \mathrm{TOC}$ ) corresponds to the quantity of oxygen released as $\mathrm{CO}$ and $\mathrm{CO} 2$, relative to TOC, and is correlated to the $\mathrm{O} / \mathrm{C}$ ratio. These parameters were defined to study mature $\mathrm{OM}$ from sedimentary rocks (e.g., Disnar, 1994), but previous works have shown that they could be used to characterize immature OM (Disnar et al., 2003).

The previous works (Giresse et al., 2009; Giresse \& Makaya-Mvoubou, 2010) mention the presence of siderite in studied cores. The analyse of deposits rich in siderite by Rock Eval analyses has some problems principally in the evaluation of the Oxygen Index because this mineral starts to decompose during the pyrolysis, when the temperature approaches $485-520^{\circ} \mathrm{C}$ (Lafargue et al., 1998). For this reason, we checked the possible influence of this mineral through (i) a study of S3 signals that measure the fluxes of $\mathrm{CO} 2$ and $\mathrm{CO}$ during pyrolysis and (ii) a comparison between the total $\mathrm{C}$ contents and the TOC. In addition, the figure 4 presents a comparison of S2 (i.e. hydrocarbon compounds produced by thermal cracking of $\mathrm{OM}$ ) and $\mathrm{S} 3 \mathrm{CO} 2$ (i.e. $\mathrm{CO} 2$ produced by thermal cracking of OM and siderite) for Kamalete samples. The correlation between the two parameters underlines the dominance of OMderived compared to mineral-derived signal. In addition, the similarities with free-siderite soil samples collected in the studied region shows the very weak possible influence of this mineral on the parameters and $\mathrm{S} 3 \mathrm{CO} \mathrm{S} 3 \mathrm{CO} 2$ measured (and hence the IO). We conclude that major changes in the IO are primarily related to sedimentary organic matter and not to the mineralogical composition (i.e. relative abundance of siderite).

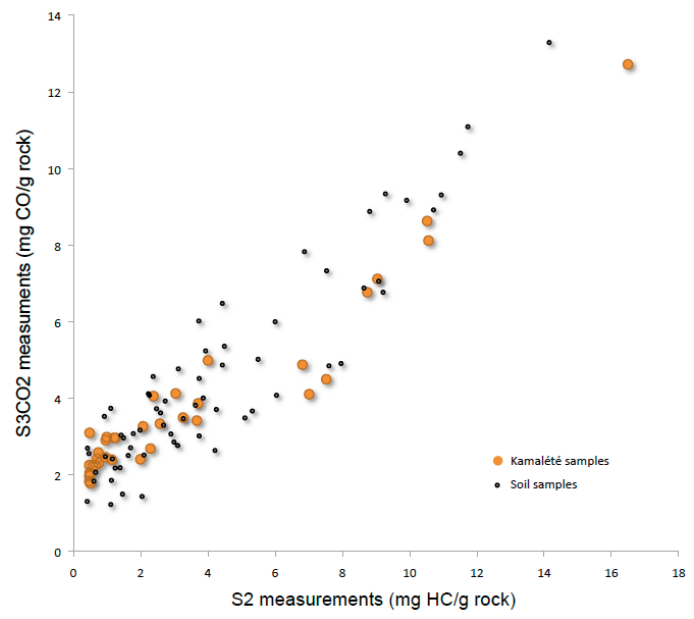

Figure 4: Correlation between S2 (i.e. hydrocarbon compounds released during thermal cracking of $O M$ ) and $\mathrm{S3CO} 2$ (i.e. $\mathrm{CO} 2$ released during thermal cracking of $O M$ and mineral constituents as siderite) measurements from KAM1 core and soil samples.

\section{Results}

\subsection{Reflectance $\left(L^{*}\right)$ and First Derivated Spectra (FDS)}

Coupling L* measurements and FDS analyses can be used to draw quantitative limits within the various lithological units, which were determined visually at the core opening.

KAM1 core. The $\mathrm{L}^{*}$ variations are used to define three units (Figure 2), which correspond to the main lithologic units described by Giresse et al. (2009). Unit 1 (from the base of clayey beige deposits to $350 \mathrm{~cm})$ presents the highest $L^{*}$ values $(>50 \%)$, followed by a decrease around $335 \mathrm{~cm}(<35 \%)$ reflecting a darker colour in this organic rich lithological boundary. Unit 2 (upper part of clayey beige deposits from 335 to $150 \mathrm{~cm}$ ) is characterized by very stable $L^{*}$ values (around $48 \%$ ). Only the dark layer located at $270 \mathrm{~cm}$ is highlighted by very low values $(<35 \%)$. Unit 3 is characterised by lower and more variable values (from 44 to $40 \%$ ), following a general decreasing trend reflecting a gradual darkening of the upper silty grey deposits (from 150 to the top).

As shown by Balsam et al. (1991, 1996, and 2003), FDS analysis can distinguish characteristic spectral signatures. This approach identifies three distinct signatures in core KAM1 (Figure 5). Two very sharp peaks, centred respectively at 435 and $545 \mathrm{~nm}$, characterize the first spectral signature A (Figure 5A). The second signature B mainly differs from the previous one by (i) a close amplitude of the two peaks at 435 and $545 \mathrm{~nm}$ and (ii) the presence of an additional broad peak centred around $675 \mathrm{~nm}$ (Figure 5B). 


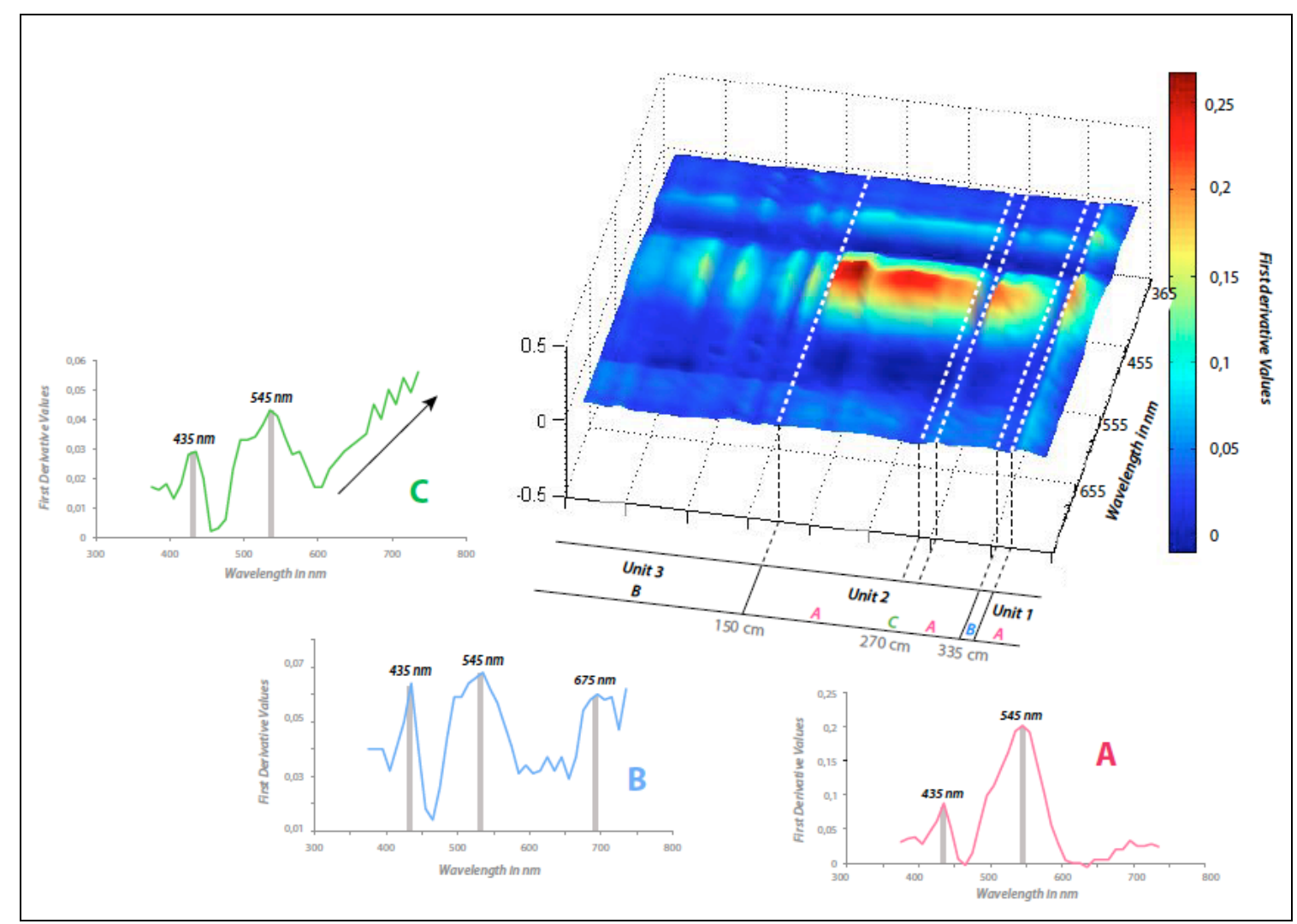

Figure 5: In-depth variations of first derivated spectra showing some compositional changes by spectrocolorimetric analysis of the KAM1 core. A, B, C: characteristic FDS of each spectral signature (see text).

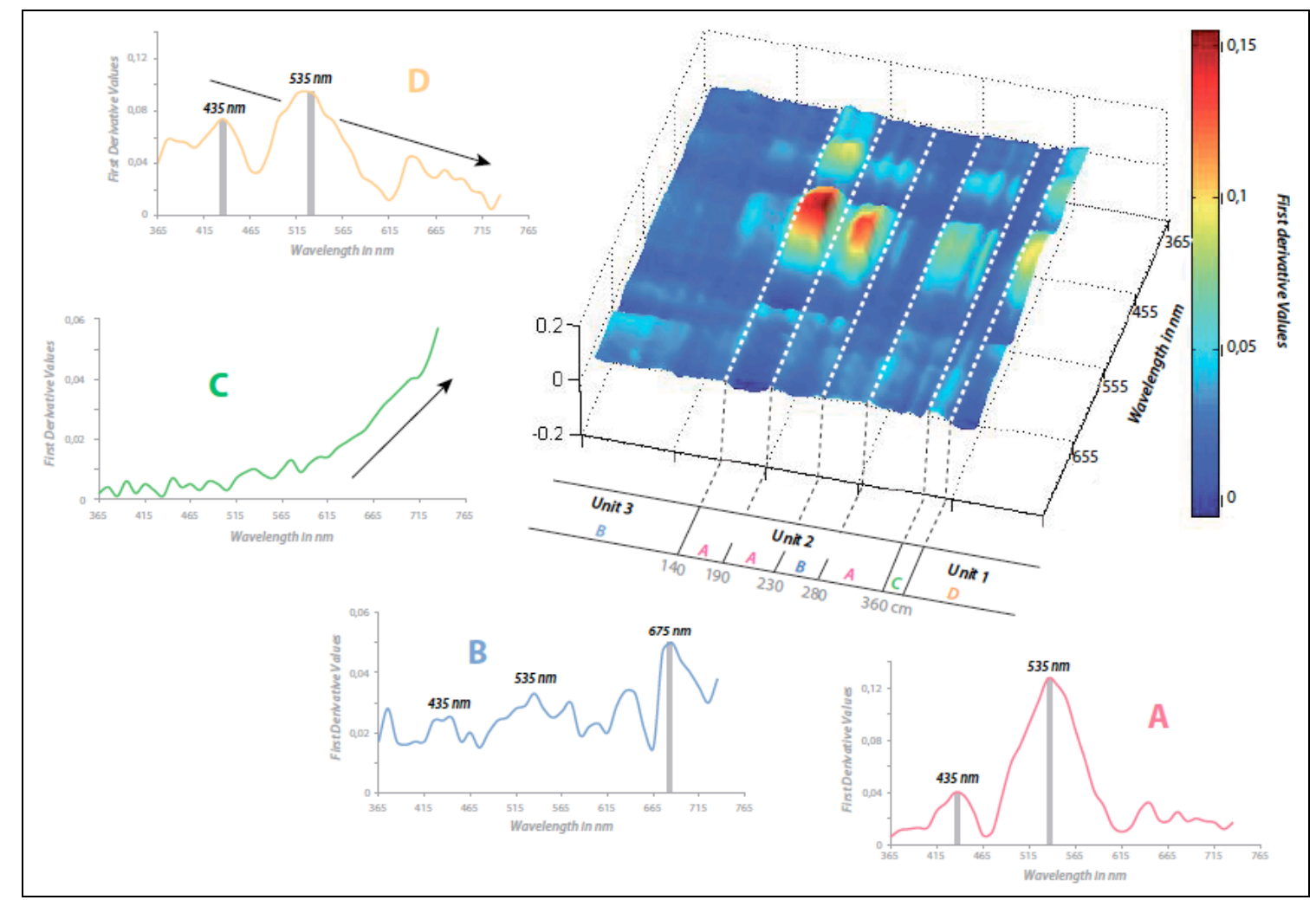

Figure 6: In-depth variations of first derivated spectra showing some compositional changes by spectrocolorimetric analysis of the NGUE1 core. A to D: characteristic FDS of each spectral signature (see text). 
Peaks at 435 and $545 \mathrm{~nm}$ are also present on the third spectral signature $\mathrm{C}$, which differs from the previous signatures by an ascending trend in seesaw pattern above $600 \mathrm{~nm}$ (Figure 5C). Finally, the indepth representation of FDS defines the lithological units previously established by Makaya Mvoubou (2005). The lower clayed beige deposits (units 1 and 2) have a dominant signature $A$, except the darkest layers around 335 and $270 \mathrm{~cm}$, which respectively have the signatures $\mathrm{B}$ and $\mathrm{C}$; the upper silty grey deposits (unit 3) present a spectral signature B (Figure 5).

NGUE1 core. Here also L* variations (Figure 3) delineate the lithological limits described by Giresse et al. (2009). Unit 1 (from the bottom of the lower gley to $370 \mathrm{~cm}$ ) is marked by a gradual decline of $\mathrm{L}^{*}$ values (from 50 to $46 \%$ ) until the darker layer highlighted by very low $\mathrm{L}^{*}$ values $(35$ to $23 \%$ ) between 370 and $340 \mathrm{~cm}$. Unit 2 (upper part of dark gley from 330 to $140 \mathrm{~cm}$ ) is characterized by a variable lightness ranging from 30 to $52 \%$, which identifies four sub-units: 330 to $290 \mathrm{~cm}$ (40 to $43 \%$ ), 280 to $230 \mathrm{~cm}$ (31 to $40 \%$ ), 230 to $190 \mathrm{~cm}$ (40 to $45 \%$ ), and 190 to $155 \mathrm{~cm}$ $(>50 \%)$. The bioturbated layer $(150-140 \mathrm{~cm})$ ending unit 2 is marked by an $\mathrm{L}^{*}$ decrease $(\sim 40 \%)$. Unit 3 , which corresponds to the upper dark deposits (from $135 \mathrm{~cm}$ to the top of the core), is characterized by low L* values between 33 and 39\%.
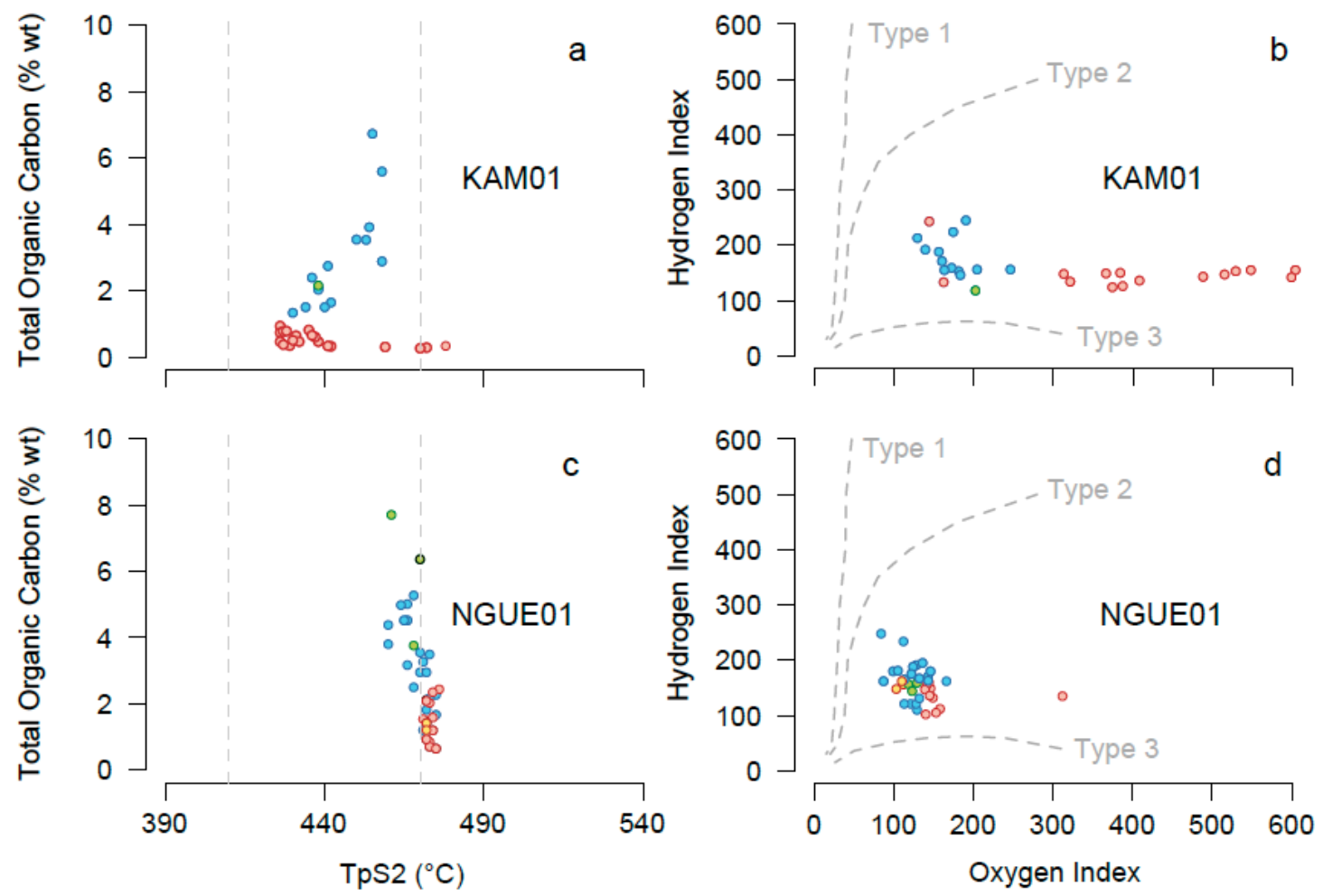

The FDS analysis identifies four distinct spectral signatures in core NGUE1 (Figure 6). Two very sharp peaks, respectively centred at 425 and 535 $\mathrm{nm}$, characterize the spectral signature A (Figure 36A). The second signature $\mathrm{B}$ is mainly characterized by a sharp peak around $675 \mathrm{~nm}$ (Fig. $6 \mathrm{~B})$. In some spectra, this peak is combined with two other weak peaks more or less visible to 435 and $545 \mathrm{~nm}$. The third signature $\mathrm{C}$ is characterized by a flat spectrum, marked by a strong increase after $600 \mathrm{~nm}$ (Fig. 6C). The fourth signature D (Fig. 6D) differs from signature A by (i) the presence of twin peaks at 435 and $535 \mathrm{~nm}$ but with rather close height and (ii) a declining trend from $360 \mathrm{~nm}$ to 700 $\mathrm{nm}$. Finally, each lithological unit is dominated by one of these four signatures (Figure 6) and is not a result of a complex mixture of the four endmembers: $\mathrm{D}$ is dominant in the bottom of the core (unit 1), C in the boundary dark layer, A and B in the intermediate light gley (unit 2), and B in the upper dark deposits (unit 3).

\subsection{Characterization of sedimentary OM}

By combining the classical Rock-Eval parameters (TOC, TpS2, HI, OI), it is possible to distinguish OM geochemical signatures (Figure 7) related to main lithological changes and to established subdivisions (Figures 2 and 3).

Figure 7: Characterization of sedimentary OM from Rock Eval parameters using two diagrams (a and c: TOCvsTpS2; b and d: HIvsOI) for comparisons between lithological units of the KAM1 and NGUE1 cores. Colours of points correspond to spectral signatures defined from FDS. 
KAM1 core. As a whole TOC and Tmax, that values range respectively from 0,3 to $6,7 \%$, and from 386 to $438^{\circ} \mathrm{C}$, respectively (Figure $7 \mathrm{a}$ ), allow us distinguishing (i) mineral OM-poor (TOC $<1 \%$, low or high Tmax), (ii) mineral OM-rich $(2 \%<$ TOC $<4 \%$, with higher Tmax), and (iii) organic facies (TOC $>5 \%$, high Tmax). This OM-base typology corresponds to lithological subdivision: e.g., lower clayey deposits (unit 2) present OMpoor facies, whereas bottom layers (unit 1) and upper silty deposits (unit 3 ) are dominated by OMrich facies. Organic facies are related to two layers located around 330 and $30 \mathrm{~cm}$ (Figure 2).

Two sample groups can be distinguished through $\mathrm{HI}$ and OI values (Figure 7b). The first group corresponds to units 1 and 3 , which presents a homogeneous OM signature typified by low $\mathrm{HI}$ values (from 133 to $245 \mathrm{HC} / \mathrm{g}$ Corg), and very low OI values (from 128 to $230 \mathrm{mg} \mathrm{O} / \mathrm{g}$ Corg). The second group, which corresponds to unit 2, presents a distinct signature marked by very low HI values (from 118 to $187 \mathrm{mg} \mathrm{HC} / \mathrm{g}$ Corg), and variable OI values (from 200 to $1500 \mathrm{mg} \mathrm{O} 2 / \mathrm{g}$ Corg).

NGUE1 core. TOC and Tmax values, that range from 0,6 to $6,4 \%$, and from 420 to $435^{\circ} \mathrm{C}$, respectively (Figure 7c), distinguish OM-poor (TOC $<2,5 \%$, constant Tmax up to $430^{\circ} \mathrm{C}$ ), OMrich $(2,5 \%<$ TOC $<6 \%$, Tmax around 430 or $425^{\circ} \mathrm{C}$ ), and organic facies (TOC $>5 \%$, Tmax around $425^{\circ} \mathrm{C}$ ). This typology corresponds to lithological subdivisions (Figure 3 ).

Low HI and OI values (from 102 to $195 \mathrm{mg} \mathrm{HC} / \mathrm{g}$ Corg, and from 84 to $166 \mathrm{mg} \mathrm{O} 2 / \mathrm{g} \mathrm{Corg}$, respectively) define a homogenous signature in the HI versus OI diagram (Figure 7d). Three samples present different signatures: two of these ones (at 135 and $125 \mathrm{~cm}$ ) have a higher HI values (ca. 240 $\mathrm{mg} \mathrm{HC} / \mathrm{g}$ Corg), and the third one (at $227 \mathrm{~cm}$ ) a higher OI value (311 mg O2/g Corg). In-depth HI variations allow us the identification of significant differences related to some lithological changes (Figure 3). Briefly, HI values are (i) stable around $155 \mathrm{mg} \mathrm{HC} / \mathrm{g}$ Corg belowr $300 \mathrm{~cm}$; (ii) comprised from 102 to $132 \mathrm{mg} \mathrm{HC} / \mathrm{g}$ Corg between 300 and $230 \mathrm{~cm}$; (iii) vary from 105 to $162 \mathrm{mg} \mathrm{HC} / \mathrm{g}$ Corg, between 230 and $150 \mathrm{~cm}$; and finally (iv) remain comprised between 149 and $248 \mathrm{mg} \mathrm{HC} / \mathrm{g}$ Corg in the unit 3 above $150 \mathrm{~cm}$.

\section{Interpretation}

Previous studies are highlighted the possibility of using spectrophotometric measurements to determine qualitative changes in sediment composition (e.g., Balsam \& Deaton, 1996; Itambi et al., 2010; Debret et al, 2011). In this way, the FDS are often used to determine some main sedimentary constituents (Barranco et al., 1989;
Balsam \& Deaton, 1991; Deaton \& Balsam, 1991). Indeed, various studies have shown that some sedimentary constituents have distinctive spectral signatures identified by the position of first derivative peaks, e.g., 445 and $525 \mathrm{~nm}$ for iron oxyhydroxides such as goethite, and 555, 565, and $575 \mathrm{~nm}$ for iron oxides such as hematite (Barranco et al., 1989), or from 605 to $695 \mathrm{~nm}$ for organic compounds, and more precisely at $675 \mathrm{~nm}$ for achlorophyll and some by-products (Wolfe et al., 2006). Here, we used these characteristic FDS peaks to determine the nature of main sedimentary constituents, and thus to define distinct spectrophotometric facies related to changes in sedimentary dynamics.

In the same way, numerous works use Rock Eval pyrolysis to analyse the bulk composition of soil and sedimentary OM (e.g., Meyers \& LallierVergès, 1999; Sebag et al., 2006). Usually, the standard parameters (TOC, HI, OI) can be used to evaluate major stages of the OM transformations in soils and sediments (mineralization, humification: Disnar et al., 2003). In addition to distinguishing terrestrial and aquatic OM, HI and OI can be used to determine the characteristic signatures of plant litter, humic horizons, and deepest organo-mineral layers (Disnar et al., 2003). Here, we use these previous studies to analyse the compositional changes of sedimentary OM in each spectrophotometric facies.

\subsection{Kamalété Lake}

The results from KAM1 samples show that some changes recorded by $\mathrm{L}^{*}$ and FDS document changes in sedimentary dynamics. Spectra analyses (Figures 5 and 6) show that typical markers of iron oxides (i.e., 435-545 twin peaks) are present on all spectra. This feature reflects the ubiquity of ironbearing constituents in the KAM1 deposits, which can be related to mineral terrigenous supplies from the catchment area. This first point is consistent with the steep slopes and colluvium mechanisms that characterize the lake watershed. In addition, our results are consistent with previous palaeoenvironmental reconstructions proposed by Ngomanda et al. (2005). For example, the base of the sediment core corresponds a savannahdominated environment dated around $1300 \mathrm{yr}$ BP. In this context, the terrigenous detrital contributions are logically produced from the soil surficial layers, rich in iron oxides (A signature) and containing a moderately degraded OM (low OI). Between 370 and $335 \mathrm{~cm}$, the pollen assemblages show an expansion of forest environments, probably in connection with wetter conditions (near the present) between 1300 and 1200 yr BP (Ngomanda et al., 2005). In this context, the first dark layer (around $335 \mathrm{~cm}$ ) corresponds to a Cyperaceae peak 
(Ngomanda et al., 2005), which can be related to a greater contribution of autochthonous primary production highlighted by the "chorophyll" specific marker (i.e., 675 peak in signature B; Wolfe et al., 2006; Debret et al., 2006; Michelluti, 2010). Above this organic level, an abrupt increase in the Pteridophytes percentage (c. 70\%) suggests significant lake-level decline (Ngomanda et al., 2005). This change is marked at the base of unit 2 by an OM-poor facies dominated by "iron oxides" markers (signature A). This back-to-a-terrigenousclastic sedimentation coincided with a period with maximum opening of the forest canopy (Ngomanda et al., 2005). The canopy opening combined with greater seasonal contrasts could then explain more intense erosion and transfer processes in the watershed. Geochemical data will complete this picture by providing information on the sources of sedimentary OM (Figures 2, 3 and 7). Indeed, high OI values ( $>300 \mathrm{mg} \mathrm{O} 2 / \mathrm{g}$ Corg) indicate a strongly altered OM (Copard et al., 2006), quite comparable with samples from deep soil horizons (Disnar et al., 2003; Mabicka Obame et al., 2009). Note that the incoherent OI value $(>1500 \mathrm{~g} \mathrm{O} 2 / \mathrm{g}$ Corg at $280 \mathrm{~cm})$ corresponds to a maximum contribution of sands and a peak in charcoal abundance (Giresse et al., 2009). It also coincides with a peak of Cyperaceae pollens (Ngomanda et al., 2005). This level can be related to a paroxysm of detritism, and may result from a seasonal high contrast, favouring runoff and mass wasting on the slopes covered with savanna. The second dark layer (around $270 \mathrm{~cm}$ ) presents a combination between "iron oxides" markers and a specific feature of altered OM (increasing trend in signature $\mathrm{C}$ ), which can be related to terrestrial peaty deposits and some oxidized coal samples probably linked to humic substance (Debret et al., 2011). In addition, low HI and OI values confirm the terrestrial OM origin. This peat layer could result from the partial filling or from a temporary drying up of the basin, around $1200 \mathrm{yr}$ BP. Ngomanda et al. (2005) note that the regression of mature forest suggests longer and/or recurring episodes of aridity from c. 1240 until 550 cal. BP. They suggest that the dry season was more prolonged and more severe than it is today. The top of unit 2 corresponds to the installation of seasonal contrasts in a drier general context. Ngomanda et al. (2005) point to a high abundance of Pteridophyte spores, which may indicate low lake-level stabilization. In addition, Giresse et al. (2009) note that the occurrence of siderite concretions in these layers denotes anoxic conditions caused by the reduction of the water input into the basin. These climatic changes are documented across equatorial Africa; they are characterized by a succession of fluctuations in the regional rainfall regime, which may be explained by shifts in the mean latitude of the intertropical convergence zone, as proposed by Nguetsop et al. (2004).

About $150 \mathrm{~cm}$, the transition to unit 3 is marked by a typical combination of "iron oxides" and "chlorophyll" markers (signature B), with very low OI values ( $<200 \mathrm{mg} \mathrm{O} 2 / \mathrm{g}$ Corg), comparable with those from surface samples of savanna soils, but with some significantly higher $\mathrm{HI}(>200 \mathrm{mg} \mathrm{HC} / \mathrm{g}$ Corg), which are quite consistent with greater autochthonous contributions (Figure 7). As revealed by Ngomanda et al. (2005), the darker units 3 is an OM-rich facies that may be related to a more humid climate, entailing a lake-level rise and progressive expansion of semi-evergreen rainforest after $550 \mathrm{yr}$ BP.

Thus, sedimentological and palaeoecological proxies (Ngomanda et al., 2005; Giresse et al., 2009) confirm our new results. Notably, Ngomanda et al. (2007) observe that, when the lake level is high, the $\delta 13 \mathrm{C}$ signal records the local vegetation, often dominated by C3 Cyperaceae, as well as the C3 plants colonizing the lake basin. Conversely, when the lake level shallows, the $\delta 13 \mathrm{C}$ signal records the isotopic composition of the local $\mathrm{C} 4$ plants (Pteridophytes and Poaceae).

\subsection{Nguène Lake}

It is important to note that the sedimentation in Nguène Lake is very different from that in the Kamalété basin. Indeed, the sedimentary dynamics in Nguène Lake is directly controlled by hydrodynamic changes of River Abanga (Giresse et al., 2009), and is therefore only little influenced by the vegetation surrounding the lake. In addition, the morphology of the watershed is not conducive to runoff and erosion as it is in Kamalété.

FDS analysis shows facies changes that we can try to relate with changes in sediment dynamics. It should be noted that the "iron oxides" twin peaks are present through the whole of the core, except in the organic layer (about $360 \mathrm{~cm}$, signature C; Figure 6).

The bottom deposits (unit 1; from 413 to $375 \mathrm{~cm}$ ) present FDS characterized by a combination of "iron oxide" markers and a specific feature of limestones (decreasing trend in signature D; Itambi et al., 2010; Debret et al., 2011). These iron deposits could be related to the presence of siderite and vivianite crystals already described by mineralogical analyses (Giresse et al., 2009). These minerals result from anoxic conditions induced by a gradual confinement of the basin around $4600 \mathrm{yr}$ BP. These pieces of information are consistent with the reconstructions proposed by Ngomanda et al. (2007) who noted that dense stands of mature rainforest occupied the catchment area during the mid-Holocene. The increase and progressive closing of forest cover would have caused a drastic 
decrease in runoff, reducing water flows from the lake watershed and thus, terrigenous proximal supplies. Accordingly, Giresse et al. (2009) pointed out that the detrital sedimentation was limited to contributions of the river Abanga between 4600 and 2460 cal yr BP. This confinement trend is highlighted by increasing TOC (Figure 3), which prefigures the installation of a "peaty marsh" (signature $\mathrm{C}$ of the organic layer around $360 \mathrm{~cm}$ ). This episode coincides with a regional environmental change as revealed by Ngomanda et al. (2007), who noted that from $4100 \mathrm{yr}$ BP surrounding evergreen rainforest was progressively replaced by semi-deciduous rainforest.

The base of unit 2 (from 350 to $280 \mathrm{~cm}$ ) presents a spectral signature dominated by "iron oxides" twin peaks (signature A) and OM-poor facies. This new facies reflects major changes that occurred in both the marsh and rainforest pollen signal. Indeed, Ngomanda et al. (2007) noted that pioneering plants progressively replaced mature rainforests between 3200 and $2400 \mathrm{yr}$ BP. This trend indicates openings in the closed canopy forest surrounding the lake basin. That might explain an accentuation of runoff and a more detrital sedimentation, and the higher sand contents measured by Giresse et al. (2009; Figure 3). Nevertheless, the absence of changes in geochemical properties (i.e., HI and OI) shows that the OM sources (surfical soil layers) have not strongly varied during these times suggesting that the river still the main contributor.

The overlying layers (from 280 to $230 \mathrm{~cm}$ ) seem to reflect a more radical change marked by the presence of the "chlorophyll" fingerprint (peak around $675 \mathrm{~nm}$ in signature B; Figure 6). This spectrophotometric fingerprint shows an autochthonous primary production, but this aquatic contribution can hide an allochthonous altered OM signature because of the low detection level of the "chlorophyll" fingerprint by spectrophotometry $(<0.01 \%$, Wolfe et al., 2006). Indeed, Rock Eval analyses (i.e. significant low HI, $<150 \mathrm{mg} \mathrm{HC} / \mathrm{g}$ Corg; Figure 3) shows the terrestrial origin of dominant OM fraction. Ngomanda et al. (2007) suggested that lake levels were lower after $2400 \mathrm{yr}$ $\mathrm{BP}$, which would explain the higher contribution of terrestrial plants, the decrease in terrigenous detrital sedimentation, and the gradual increase of sand contents (Giresse et al., 2009; Figure 3).

A change in spectrophometric facies (around 240 $\mathrm{cm})$ is highlighted by the highest OI value $(>300$ $\mathrm{mg} \mathrm{O} 2 / \mathrm{g}$ Corg), which is consistent with more intense weathering and erosion processes in the catchment area. This layer marks the change toward the upper unit 2 (from 230 to $150 \mathrm{~cm}$ ), and presents the same colour properties as the lower part ("iron oxides" signature A). These detrital facies, however, are distinguished by the lack of sand, which may indicate that the sources have changed, or that the lake basin is protected by coarser inputs. Ngomanda et al. (2007) note that maximal regression of the mature evergreen rainforest occurred between 2000 and 1450 yr BP.

Unit 3 corresponds to the installation of lacustrine conditions, with significant autochthonous primary production ("chlorophyll" in signature B, high HI values). This hypothesis is confirmed by pollen analyses, which indicate that the basin became a proper lake, but was marked by recurring seasonal fluctuations. Thus, the pollen assemblages suggest that an open forest occupied the catchment and the mean water level of the lake was lower prior to 1450 yr BP (Ngomanda et al., 2007). The same authors indicate that the marsh expanded in response to the increasingly long duration of lower lake levels from c. 1450 to 1250 cal yr BP. Ngomanda et al. (2007) note the renewed spread of dense closed canopy rainforest in the catchment and an expansion of swamp forest and probably higher water levels in the lake basin after $950 \mathrm{yr}$ BP.

From 950 yr BP, lacustrine conditions result not only from rainfall (with a consequential increase of canopy), but also from changes in the Abanga hydrodynamics, which then feeds the lake with a suspended sedimentary load. Note here that Abanga is very high compared to the lake. There is therefore no possible drain for the lake into the Abanga river (Giresse et al., 2009).

\section{FDS analysis, OM properties, and palaeoenvironmental proxies}

In recent years, Nguène Lake and Kamalété Lake have been studied repeatedly, providing comprehensive reconstructions of environmental changes over the last millennia (Ngomanda et al., 2005; Ngomanda et al., 2007; Giresse et al., 2009; Giresse \& Makaya-Mvoubou, 2010). Thus, we do not dwell on probable or even proven causes of these changes, referring to the previous studies. In this way, Table 1 synthesises additional information gained for the particular study sites. However, this work is the first combination of Rock Eval pyrolysis and spectrophotometry applied to the study the Holocene lake deposits from tropical moist forests. In this methodological perspective, the two lakes considered have sufficient commonalities and differences to provide a controlled assessment of the methods used and the various reference terms for future studies.

In the studied cases, this double approach allowed us identifing the facies dominated by detrital terrigenous inputs ("iron oxides" signature and high OI values) and those associated with a more abundant primary OM production ("chlorophyll" signature, low OI and high $\mathrm{HI}$ ), providing a distinction between palustrine and lacustrine 
dynamics. However, although the facies are comparable, sedimentary dynamics and sediment sources may vary depending on geomorphological and climatic contexts. Thus, the lower detrital sequence of Kamalété Lake corresponds to the intense processes of erosion and colluviation on the slopes of the very narrow watershed (Giresse et al., 2009). On the other hand, Nguène Lake is located in a different context, surrounded by forested lowlands but frequently supplied by Abanga River waters. Here, the detrital sequence is interpreted as resulting from fluvial inputs derived from the upstream part of the Abanga River. During these times, lake-level fluctuations could be related to regional climate changes. Thus, the first $\mathrm{OM}$ change ("chlorophyll" signature but low HI), dated around 2400 cal. yr BP, could have been caused by a diminution in the mean rainfall and, mainly in the sedimentary inputs from river overflow, inducing a relative increase of terrigenous supplies. Inversely, the upper lacustrine sequence ("chlorophyll" signature, high $\mathrm{HI}$ ) would be related to increasing rainfall and more frequent Abanga River floods since 1900 cal. yr BP.

In addition, this comprehensive approach also distinguishes between OM-rich facies from terrestrial origin and those related to accumulation of aquatic OM, providing general information about the sources of sedimentary OM. Thus, a specific signature of altered terrestrial OM ("oxidized OM" in signature $\mathrm{C}$, low $\mathrm{HI}$ and $\mathrm{OI}$ ) should reflect the installation of swamp and/or anoxic conditions before 2700 cal. yr BP in the Nguène basin, and around 1180 cal. yr BP in the Kamalété basin. On the other hand, for more details about this sedimentary OM, Rock Eval pyrolysis provides bulk geochemical indices, which can be used to track the soil horizon-sources of terrigenous OM in detrital swamp (OI variations in KAM1 core), or to draw water-level variations in a more lacustrine system (HI variations in NGUE1 core).

Table 1: Contributions of "Spectrophotometry and Rock-Eval" coupled approach compared to more classical techniques used in previous studies for the particular study sites.

\begin{tabular}{|l|l|l|l|}
\cline { 2 - 4 } \multicolumn{1}{c|}{} & \multicolumn{1}{|c|}{$\begin{array}{c}\text { Mineralogy } \\
\text { X-ray Diffraction }\end{array}$} & $\begin{array}{l}\text { Organic geochemistry } \\
{ }^{13} \text { C/12C and C/N ratios }\end{array}$ & $\begin{array}{l}\text { Paleoenvironmental } \\
\text { reconstructions } \\
\text { Palynology }\end{array}$ \\
\cline { 2 - 4 } & $\begin{array}{l}\text { To estimate relative } \\
\text { contributions of specific } \\
\text { mineral constituents in } \\
\text { isolated samples. }\end{array}$ & $\begin{array}{l}\text { To identify origin and/or } \\
\text { quantify degradation of } \\
\text { organic fraction. }\end{array}$ & $\begin{array}{l}\text { To identify and characterize } \\
\text { the environmental } \\
\text { responses of terrestrial } \\
\text { ecosystems to climatic and } \\
\text { anthropogenic changes. }\end{array}$ \\
\hline $\begin{array}{l}\text { Spectrophotometry } \\
\text { Non-destructive analyses } \\
\text { producing a high-resolution } \\
\text { signal }\end{array}$ & $\begin{array}{l}\text { To define characteristic } \\
\text { facies from mineral or } \\
\text { organic color-bearing } \\
\text { constituents. }\end{array}$ & $\begin{array}{l}\text { To determine the aquatic or } \\
\text { terrestrial origin, and the } \\
\text { proximal or distal sources of } \\
\text { organic fraction. }\end{array}$ & $\begin{array}{l}\text { To identify and characterize } \\
\text { the sedimentary responses } \\
\text { of lacustrine dynamics in } \\
\text { response to local and } \\
\text { regional environmental } \\
\text { changes. }\end{array}$ \\
\hline $\begin{array}{l}\text { Rock Eval pyrolysired pretreatments and } \\
\text { semi-automatized process }\end{array}$ & uninformative \\
\hline
\end{tabular}

\section{Conclusion}

Previous works have shown that FDS features may be related to some sedimentary constituents. Here, we show that these features may be used to establish spectrophotometric facies reflecting major lithological changes. Coupled with these comprehensive measurements, the Rock Eval parameters can be used to determine the sources of sedimentary OM, to analyse the changes in sedimentary dynamics, and to track the evolution of depositional environments.

In summary, the combination of spectrophotometric and Rock Eval measurements of the Kamalété core highlights a drastic change in sedimentary dynamics around $500 \mathrm{yr}$ BP. The first part of the record $(>150 \mathrm{~cm})$ is dominated by detrital terrigenous inputs (signature A, high OI) in the swampy environment, probably consequential to intense erosional processes in the watershed. The second part $(<150 \mathrm{~cm})$ is marked by an apparent increase of local primary production (signature B, low OI), which can be induced by an attenuation of detrital terrigenous fluxes in a lacustrine basin.

In Nguène core, the combination of FDS analysis and Rock Eval pyrolysis allowed us to identify two separate episodes: signature A ("iron oxides") and low $\mathrm{HI}$ values $(<150 \mathrm{mg} \mathrm{HC} / \mathrm{g}$ Corg) in basal deposits (units 1 and 2), as a result of erosion of soil surface layers; and signature B ("chlorophyll") and high $\mathrm{HI}$ values (>150 mg HC/g Corg) in the upper deposits (unit 3), consistent with higher autochthonous contribution. These drastic changes are coherent with previous works concluding on the replacement of swamp conditions, marked by changes in water level and/or fluctuations in fluvial flooding, by permanent lacustrine conditions. In 
addition, small variations in FDS and HI (and OI) values could be related to minor changes in sedimentary dynamics, OM sources, or terrigenous input frequencies, as documented from palynological and geochemical data.

From a methodological perspective, this work is similar to a calibration on well-documented reference cores, which validates matching techniques, and provides elements of comparison for future studies. The spectrophotometric analysis can be performed quickly after the coring, and it produces a high-resolution signal (up to $0.5 \mathrm{~cm}$ ), which assesses the quality of the sedimentary records and guides the sampling strategy. Rock Eval pyrolysis does not require pretreatments, and it can provide comprehensive information on the quality and nature of sedimentary OM. The combined use of both techniques seems to be an appropriate response to a preliminary analysis of lake deposits of humid tropical forests.

\section{Acknowledgments}

This study was conducted under the OMARD action (Organic Markers Dynamics in tropical terrestrial environments) funded by the FED 4116 SCALE with support from the Institut de Recherche pour le Développement (IRD), the University of Masuku (USTM, Gabon), and the University of Rouen (France).

\section{References}

Balsam, W.L., \& Deaton, B.C. (1991). Sediment dispersal in the Atlantic-ocean - Evaluation by visiblelight spectra. Reviews in Aquatic Sciences, 4(4), 411447.

Balsam, W.L., \& Deaton, B.C. (1996). Determining the composition of late quaternary marine sediments from NUV, VIS, and NIR diffuse reflectance spectra. Marine Geology, 134(1-2), 31-55.

Balsam, W. L., \& Beeson, J. P. (2003). Sea-Floor sediment distribution in the Gulf of Mexico. Deep Sea Research Part I: Oceanographic Research Papers, 50(12), 1421-1444.

Barranco, F.T., Balsam, W.L., \& Deaton, B.C. (1989). Quantitative reassessement of brick red lutites - Evidence from réflectance spectrophotometry. Marine Geology, 89(3-4), 299-314.

Bassot, J.P. 1988. Apports de la télédétection à la compréhension de la géologie du Gabon. Chron. rech. min. 491, 25-34.

Behar, F., Beaumont, V., \& HL, H. (2001). Rock-Eval 6 technology: Performances and developments. Oil \& Gas Science and Technology, 56(2), 111-134.

Bonnefille, R. 2011. Rainforest responses to past climatic changes in tropical Africa, in: Bush, M.B., Flenley, J.R., Gosling, W.D. (Eds.), Tropical Rainforest Responses to Climatic Change (2nd edition). Springer/Praxis, Chichester, pp. 125-184.

Chatelin, Y. 1966. Essai de classification des ferrallitiques du Gabon. Cahiers ORSTOM, série pédologie IV, 4, 45-60.

Collinet, J. \& Martin, D. 1973. Carte pédologique de reconnaissance à 1/200.000e. Feuille de Lambaréné. ORSTOM, Paris. Notice explicative ${ }^{\circ} 50,100 \mathrm{p}$.

Copard, Y., Di-Giovanni, C., Martaud, T., Albéric, P., \& Olivier, J. E. (2006). Using rock-eval 6 pyrolysis for tracking fossil organic carbon in modern environments: Implications for the roles of erosion and weathering. Earth Surface Processes and Landforms, 31(2), 135-153.

Croft, D.J., \& Pye, K. (2004). Multi-technique comparison of source and primary transfer soil samples: an experimental investigation. Science \& Justice, 44(1), 21-28.

Deaton, B.C., \& Balsam, W.L. (1991). Visible spectroscopy - a rapid method for determining hématite and goethite concentration in geological materials. Journal of Sedimentary Geology, 61(4), 628-632.

Debret, M., Desmet, M., Balsam, W., Copard, Y., Francus, P., \& Laj, C. (2006). Spectrophotometer analysis of Holocene sediments from an anoxic fjord: Saanich inlet, British Columbia, Canada. Marine Geology, 229(1-2), 15-28.

Debret, M., Chapron, E., Desmet, M., Rolland-Revel, M., Magand, O., Trentesaux, A., Bout-Roumazeille, V., Nomade, J., \& Arnaud, F. (2010). North-western Alps Holocene paleohydrology recorded by flooding activity in Lake Le Bourget, France. Quaternary Science Reviews, 29(17-18).

Debret, M., Sebag, D., Desmet, M., Balsam, W., Copard, Y., Mourier, B., Susperrigui, A.-S., Arnaud, F., Bentaleb, I., Chapron, E., Lalliers-Vergès, E., \& Winiarski, T. (2011). Spectrocolorimetric interpretation of sedimentary dynamics: the new "Q7/4 diagram". Earth-Sciences Review, 109, 1-19

Di-Giovanni, C., Disnar, J.R., Bichet, V., Campy, M., \& Guillet, B. (1998). Geochemical characterization of soil organic matter and variability of a Postglacial detrital organic supply (Chaillexon Lake, France). Earth Surface Processes and Landforms, 23(12), 1057-1069.

Disnar, J. R. (1994). Determination of maximum paleotemperatures of burial (MPTB) of sedimentary rocks from pyrolysis data on the associated organic matter: Basic principles and practical application. Chemical Geology, 118(1-4), 289-299.

Disnar, J. R., Guillet, B., Keravis, D., Di-Giovanni, C., \& Sebag, D. (2003). Soil organic matter (SOM) characterization by Rock-Eval pyrolysis: Scope and limitations. Organic Geochemistry, 34(3), 327-343.

Dupont, L. M., Jahns, S., Marret, F., \& Ning, S. (2000). Vegetation change in equatorial West Africa: Time-Slices for the last $150 \mathrm{ka}$. Palaeogeography, Palaeoclimatology, Palaeoecology, 155(1-2), 95-122.

Espitalié, J., Deroo, G., \& Marquis, F. (1985). Rock val pyrolysis and its applications. Revue de l'Institut francais du Petrole, 40(5), 563-579.

Giresse, P., \& Makaya Mvoubou. (2010). Sediment and particulate organic carbon fluxes in various lacustrine basins of tropical Africa and in the Gulf of Guinea. Global and Planetary Change, in press.

Giresse, P., Mvoubou, M., Maley, J., \& Ngomanda, A. (2009). Late-Holocene equatorial environments inferred 
from deposition processes, carbon isotopes of organic matter, and pollen in three shallow lakes of Gabon, westcentral Africa. Journal of Paleolimnology, 41(2), 369392.

Hetényi, M., Nyilas, T., \& Toth, T. M. (2005). Stepwise Rock-Eval pyrolysis as a tool for typing heterogeneous organic matter in soils. Journal of Analytical and Applied Pyrolysis, 74(1-2), 45-54.

Itambi, A. C., von Dobeneck, T., \& Adegbie, A. T. (2010). Millennial-Scale precipitation changes over central africa during the Late Quaternary and Holocene: Evidence in sediments from the Gulf of Guinea. Journal of Quaternary Science, 25(3), 267-279.

Ji, J., Shen, J., Balsam, W., Chen, J., Liu, L., \& Liu, X. (2005). Asian monsoon oscillations in the northeastern Qinghai-Tibet plateau since the Late Glacial as interpreted from visible reflectance of Qinghai lake sediments. Earth and Planetary Science Letters, 233(1-2), 61-70.

Kim, S.Y., Scourse, J., Marret, F., \& Lim, D.I. (2010). A 26,000-year integrated record of marine and terrestrial environmental change off Gabon, west equatorial Africa. Palaeogeography Palaeoclimatology Palaeoecology, 297(2), 428-438.

Kossoni, A., \& Giresse, P. (2010). Interaction of Holocene infilling processes between a tropical shallow lake system (Lake Ossa) and a nearby river system (Sanaga River)(South Cameroon). Journal of African Earth Sciences, 56(1), 1-14.

Lafargue, E., Marquis, F., \& Pillot, D. (1998). Rock-Eval 6 applications in hydrocarbon exploration, production, and soil contamination studies. Oil \& Gas Science and Technology, 53(4), 421-437.

Lézine, A. M., Duplessy, J. C., \& Cazet, J. P. (2005). West African monsoon variability during the last deglaciation and the Holocene: Evidence from fresh water algae, pollen and isotope data from core KW31, Gulf of Guinea. Palaeogeography, Palaeoclimatology, Palaeoecology, 219(3-4), 225-237.

Mabicka Obame, R., Maniougou, M., Sebag, D., Copard, Y., Di-Giovanni, C., Boussafir, M., Mbina, M. \& Durand, A. (2009). Organic matter characterisation of some tropical soils (Nyanga catchment, SW Gabon) with Rock Eval 6 pyrolysis. 27nd IAS Meeting of Sedimentology, Alghero, Italia, 20-23 September 2009. pp. 257.

Makaya Mvoubou, 2005. Les paléoenvironnements sédimentaires fini-holocènes de trois lacs du Gabon (Kamalété, Nguène et Maridor). Études sédimentologique et biogéochimiques. Doct. Thesis, Perpignan University, $261 \mathrm{p}$.

Maley, J., \& Brenac, P. (1998). Vegetation dynamics, palaeoenvironments and climatic changes in the forests of western Cameroon during the last 28,000 years BP. Review of Palaeobotany and Palynology, 99(2), 157-187.

Marchand, C., Lallier-Vergès, E., \& Baltzer, F. (2003). The composition of sedimentary organic matter in relation to the dynamic features of a mangrove-fringed coast in French Guiana. Estuarine, Coastal and Shelf Science, 56(1), 119-130.

Marchant, R., \& Hooghiemstra, H. (2004). Rapid environmental change in African and South American tropics around 4000 years before present: A review. Earth-Science Reviews, 66(3-4), 217-260.
Marret, F., Maley, J., \& Scourse, J. (2006). Climatic instability in west equatorial Africa during the Mid-and Late Holocene. Quaternary International, 150(1), 71-81.

Meyers, P. A., \& Lallier-Vergès, E. (1999). Lacustrine sedimentary organic matter records of Late Quaternary paleoclimates. Journal of Paleolimnology, 21(3), 345372.

Michelutti, N., Blais, J.M., Cumming, B.F., Paterson, A.M., Rühland, K., Wolfe, A.P., \& Smol, J. P. (2010). Do spectrally inferred determinations of chlorophyll a reflect trends in lake trophic status? Journal of Paleolimnology, 43(2), 205-217.

Mix, A.C., Rugh, W., Pisias, N.G., \& Veirs, S. (1992). Color reflectance spectroscopy: A tool for rapid characterization of deep-sea sediments. Proceedings of the Ocean Drilling Program, Initial Reports, 138, 67-77.

Mix, A.C., Harris, S.E., \& Janecek, T.R. (1995). Estimating lithology from nonintrusive reflectance spectra: Leg 138. In Proceedings of the ocean drilling program, Scientific results. 138, 413-427.

Ngomanda, A., Chepstow-Lusty, A., Makaya, M., Schevin, P., Maley, J., Fontugne, M., Oslisly, R., Rabenkogo, N., Jolly, D. (2005). Vegetation changes during the past 1300 years in western equatorial afnrca: A high resolution pollen record from Lake Kamalete, Lope Reserve, Central Gabon. The Holocene, 15(7), 1021.

Ngomanda, A., Jolly, D., Bentaleb, I., \& ChepstowLusty, A. (2007). Lowland rainforest response to hydrological changes during the last 1500 years in Gabon, western equatorial Africa. Quaternary Research, 67(3), 411-425.

Ngomanda, A., Neumann, K., Schweizer, A., \& Maley, J. (2009). Seasonality change and the third millennium BP rainforest crisis in southern Cameroon (Central Africa). Quaternary Research, 71(3), 307-318.

Nguetsop, V.F., Servant-Vildary, S., \& Servant, M. (2004). Late Holocene climatic changes in west Africa, a high resolution diatom record from equatorial Cameroon. Quaternary Science Reviews, 23(5-6), 591-609.

Nguetsop, F. V., Servant-Vildary, S., Servant, M., \& Roux, M. (2010). Long and short time-scale climatic variability in the last 5500 years in Africa according to modern and fossil diatoms from Lake Ossa (WesternCameroon). Global and Planetary Change, in press.

Ortiz, J. D., Polyak, L., Grebmeier, J. M., Darby, D., Eberl, D. D., Naidu, S., \& Nof, D. (2009). Provenance of holocene sediment on the Chukchi-Alaskan margin based on combined diffuse spectral reflectance and quantitative $\mathrm{x}$-ray diffraction analysis. Global and Planetary Change, 68(1-2), 73-84.

Patience, A. J., Lallier-Verges, E., Alberic, P., Desprairies, A., \& Tribovillard, N. (1996). Relationships between organo-mineral supply and early diagenesis in the lacustrine environment: A study of surficial sediments from the lac du bouchet (haute loire, france). Quaternary Science Reviews, 15(2-3), 213-221.

Russell, J. M., \& Johnson, T. C. (2005). A highresolution geochemical record from Lake Edward, Uganda Congo and the timing and causes of tropical African drought during the late Holocene. Quaternary Science Reviews, 24(12-13), 1375-1389.

Sanei, H., Stasiuk, L. D., \& Goodarzi, F. (2005). Petrological changes occurring in organic matter from 
recent lacustrine sediments during thermal alteration by rock-eval pyrolysis. Organic Geochemistry, 36(8), 11901203.

Sangen, M. (2010). New results on palaeoenvironmental conditions in equatorial Africa derived from alluvial sediments of Cameroonian rivers. Proceedings of the Geologists' Association, 122(1), 212-223.

Sebag, D., Disnar, J.R., Guillet, B., Di Giovanni, C., Verrecchia, E.P., \& Durand, A. (2006). Monitoring organic matter dynamics in soil profiles by 'Rock-Eval pyrolysis': bulk characterization and quantification of degradation. European Journal of Soil Science, 57(3), 344-355.

Sifeddine, A., Laggoun-Défarge, F., Lallier-Vergès, E., Disnar, J. R., Williamson, D., Gasse, F., \& Gibert, E. (1995). Lacustrine organic sedimentation in the southern tropical zone in the last 36 kyears (Lake Tritrivakely, Madagascar). Comptes Rendus de l'Académie des Sciences. Série 2. Sciences de la Terre et des Planètes, 321(5), 385-391.

Thomas, M. F., \& Thorp, M. B. (2003). Palaeohydrological reconstructions for tropical Africa since the Last Glacial Maximum: evidence and problems. In K. J. Gregory \& G. Benito (Eds.), Palaeohydrology: Understanding global change. (p. 167).
Wiley.

Ward, P. J., Aerts, J. C. J. H., de Moel, H., \& Renssen, H. (2007). Verification of a coupled climate-hydrological model against Holocene palaeohydrological records. Global and Planetary Change, 57(3-4), 283-300.

Weber, F. 1968. Une série précambrienne du Gabon : le Francevillien. Sédimentologie, géochimie, relations avec les gîtes minéraux associés. Mém. Serv. Carte géol. Als. Lorr., Strasbourg, 28, 328p.

Weldeab, S., Lea, D. W., Schneider, R. R., \& Andersen, N. (2007). Centennial scale climate instabilities in a wet early Holocene West African monsoon. Geophys. Res. Lett, 34 .

Wolfe, A. P., Vinebrooke, R. D., Michelutti, N., Rivard, B., \& Das, B. (2006). Experimental calibration of lakesediment spectral reflectance to chlorophyll a concentrations: Methodology and paleolimnological validation. Journal of Paleolimnology, 36(1), 91-100.

Zhang, Y. G., Ji, J., Balsam, W. L., Liu, L., \& Chen, J. (2007). High resolution hematite and goethite records from ODP 1143, south china sea: Co-Evolution of monsoonal precipitation and el niño over the past 600,000 years. Earth and Planetary Science Letters, 264(1-2), 136-150. 